\title{
PHOTOVOLTAIC PANEL RECYCLING: FROM TYPE-SELECTIVE PROCESSES TO FLEXIBLE APPARATUS FOR SIMULTANEOUS TREATMENT OF DIFFERENT TYPES
}

\author{
Francesca Pagnanelli \\ Department of Chemistry, Sapienza University of Rome, P.le Aldo Moro 5, 00185 Rome, Italy
}

Keywords: Photovoltaic panels, secondary raw materials, physical pretreatment, hydrometallurgy, metal recovery

\begin{abstract}
Photovoltaic (PV) technology for renewable energy utilization is constantly growing throughout the world. This widespread application is going to determine the disposal of large amounts of wastes (as end of life panels): only in Europe about 500,000 ton/year are expected in the next 20 years. European Union issued the Guideline 2012/19/EU in order to fix rules about end of life photovoltaic panel's treatment establishing both collecting rates and minimum recovery targets. Currently the dominant PV technology uses crystalline silicon (monocrystalline and polycrystalline) as semiconductor, but the thin film photovoltaic modules using cadmium telluride (CdTe), amorphous silicon, Copper Indium Gallium Selenide (CIGS) and Copper Indium Selenide (CIS) are recently getting much more importance. Wastes of PV installations are secondary raw materials which could be treated in order to recover glass and Al, but also other metals such as $\mathrm{Cu}$, Ti, $\mathrm{Ag}$, Te, $\mathrm{In}, \mathrm{Se}, \mathrm{Ga}$, along with plastic and metallic components of electronic equipment.

Many recent efforts were devoted to treatment of end of life panels, but only two full scale processes were developed for crystalline silicon modules (Deutsche Solar) and CdTe panels (First Solar). Further recent developments concerned with new technologies designed for treating together more kinds of photovoltaic panels by automated processes. In this work a picture of the PV world in terms of market, typology, waste dynamics and recoverable materials will be given. A description of full scale processes will be reported evidencing products and yields of recovery. A case study of process development for the simultaneous treatment of different kinds of PV panels will be presented. In particular experimental results in lab and pilot scale will be described regarding the development and optimization of a process including both physical pretreatment and hydrometallurgical recovery of target metal concentrates.
\end{abstract}

\section{INTRODUCTION}

\section{Photovoltaic Technologies}

Photovoltaic installations during the last years have been growing exponentially with European PV markets accounting for $80 \%$ of global demand. Recent reduction (2011) in subsidy levels across the major European markets didn't have a decisive effect due to emerging markets such as India, US, Canada, Australia and others countries which are going to have a great deal of growth momentum, which could even be sufficient to offset the impact of weakening European demand. In Figure 1 the trend of global installation in the last years is reported evidencing the previously described trend. 


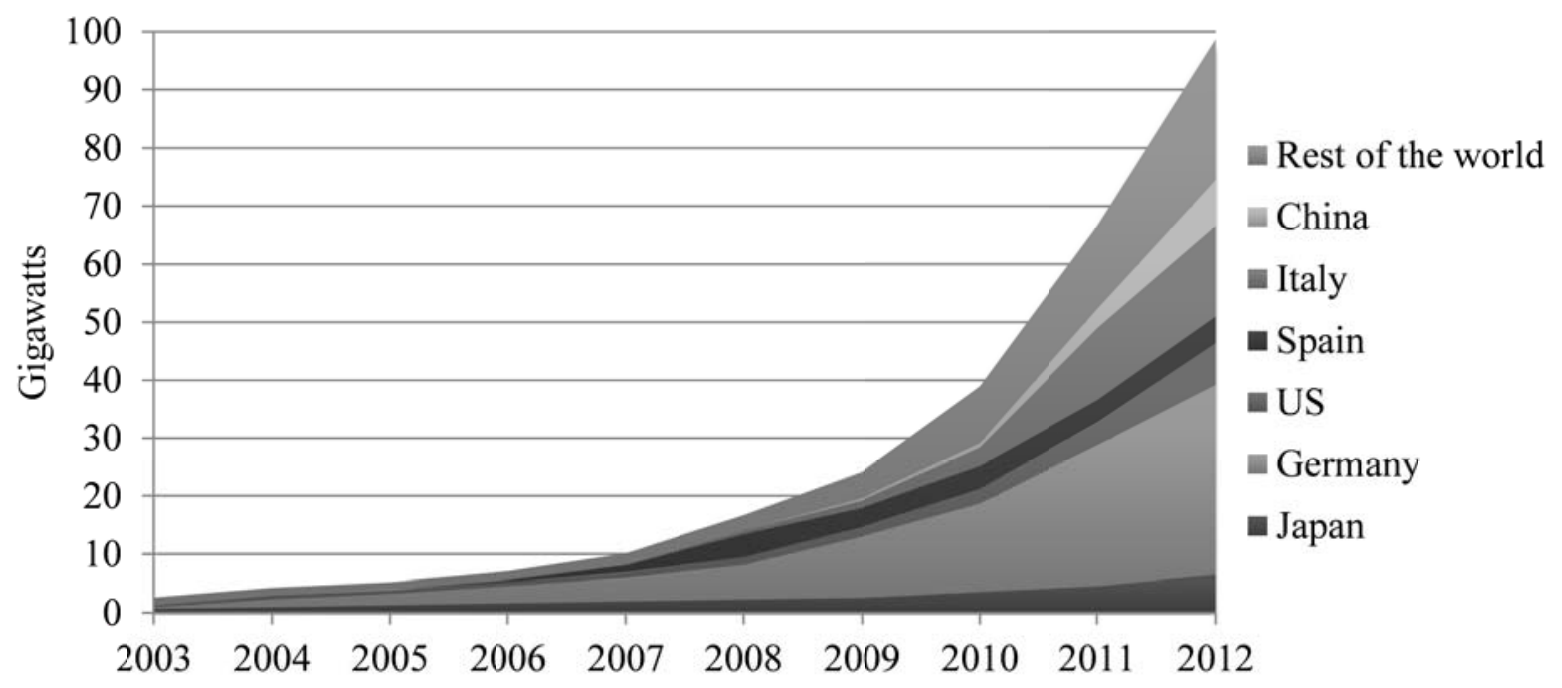

Figure 1. Photovoltaic generation capacity ${ }^{1}$

Photovoltaic panels can be classified according to three main categories or generations as reported in Figure 2. First generation panels are based on crystalline silicon both in monocrystalline and polycrystalline form. Second generation panels are thin film based on different materials such as amorphous silicon, cadmium telluride (CdTe), copper indium gallium selenide (CIS and CIGS).

Third generation panels include concentrator photovoltaics and emerging technologies such as dye-sensitised solar cells, organic solar cells, and hybrid cells.

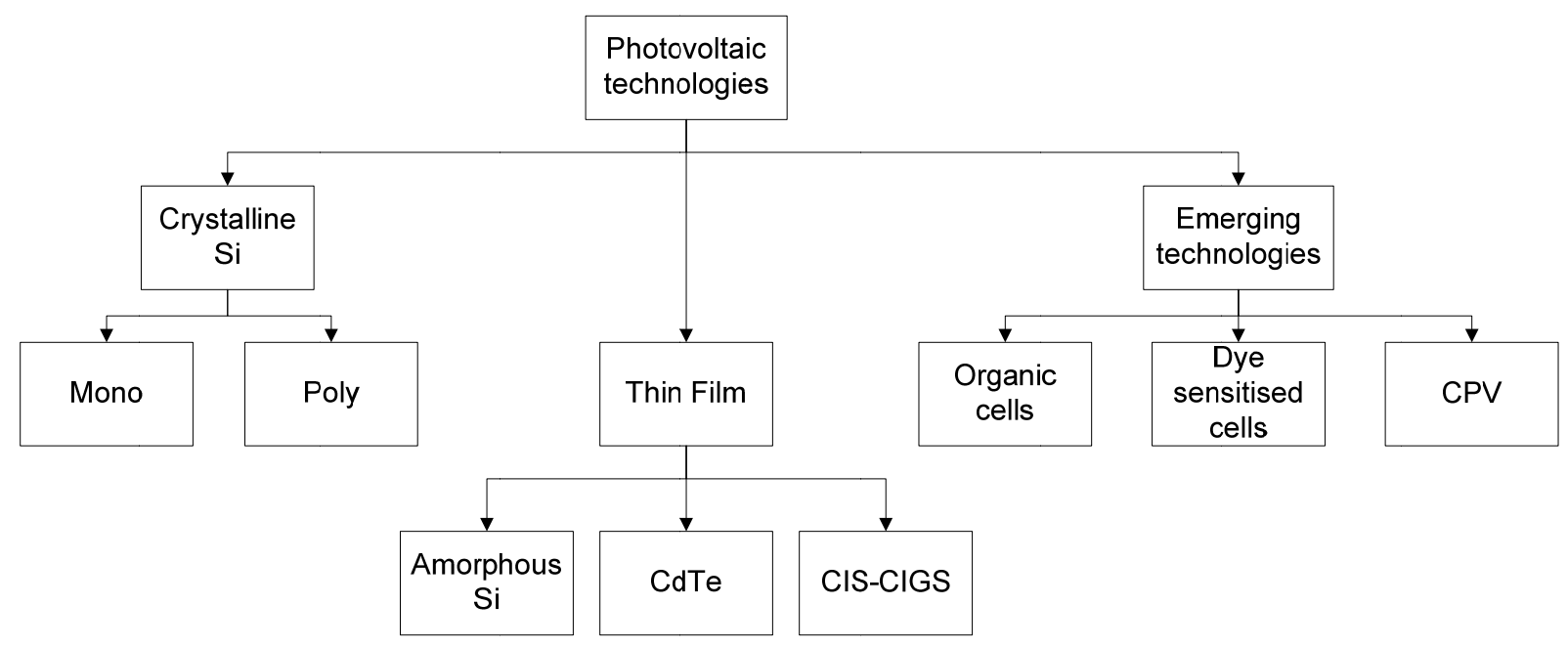

Figure 2. Photovoltaic panel classification.

The three generations differ for dimensions, weigh, energetic performances, and composition ${ }^{2}$ as evidenced in Table 1.

In Figure 3 a detail about the internal composition of multilayer structures for the different panel types is reported. 


\begin{tabular}{|l|c|c|c|c|}
\hline & Crystalline Si & Amorphous Si & CdTe & CIS-CIGS \\
\hline Module weight (Kg) & $5-28$ & $11-20$ & $9-15$ & $10-20$ \\
\hline Normal capacity (Wp) & $120-300$ & $60-120$ & $60-120$ & $60-120$ \\
\hline Size range $\left(\mathrm{m}^{2}\right)$ & $1.4-1.7$ & $1.4-5.7$ & $0.6-1$ & $0.6-1$ \\
\hline Glass & $74 \%$ & $86 \%$ & $95 \%$ & $84 \%$ \\
\hline Aluminum & $10 \%$ & $<1 \%$ & $<1 \%$ & $12 \%$ \\
\hline $\begin{array}{l}\text { Other components } \\
\text { (including rare metals) }\end{array}$ & $16 \%$ & $14 \%$ & $4 \%$ & $4 \%$ \\
\hline Rare metals & $\mathrm{Ag}$ & $\mathrm{In}, \mathrm{Ge}$ & - & $\mathrm{In}, \mathrm{Ga}$ \\
\hline Toxic metals & $\mathrm{Pb}$ & - & $\mathrm{Cd}$ & $\mathrm{Cd}$ \\
\hline
\end{tabular}

Table 1. Typical characteristics of first and second generation photovoltaic panels.
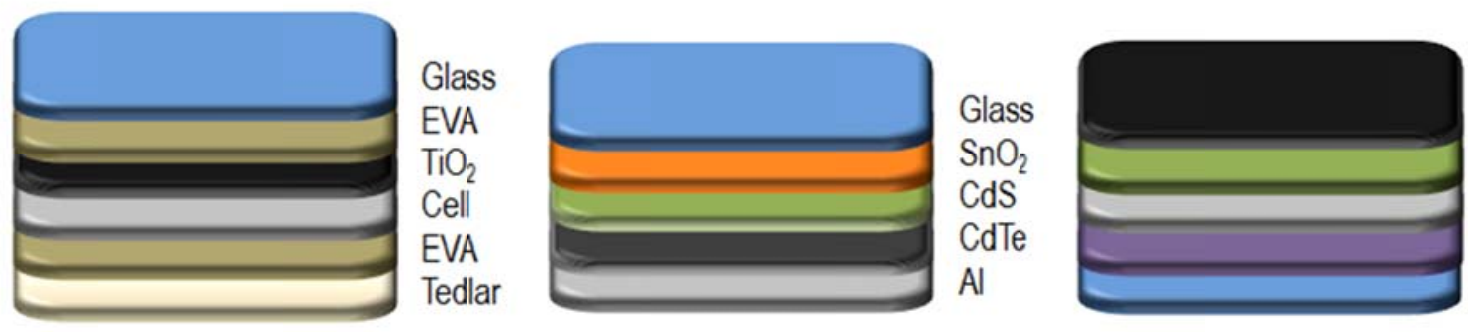

$\mathrm{ZnO}$

CdS

CIGS

Mo

Glass

Figure 3. Multilayer composition of photovoltaic panels.

First generation panels are the most diffuse (globally mono and polycrystalline are about $80 \%$ of the total market,) while thin film panels cover a little but growing portion of the rest of the market.

\section{Regulations}

Dramatic increase of photovoltaic installation could be a solution to fossil fuel depletion in terms of renewable energy source. Nevertheless photovoltaic energy production will give rise to an environmental problem related to the generation of huge amounts of end of life panels.

Taking into account panel composition main environmental concerns arise for possible pollutant release due to leaching of heavy metals such as lead and cadmium. In addition environmental impacts related to loss of conventional resources (such as glass and aluminum) and rare metals (silver, indium, gallium, germanium).

European Directive 2012/19/EU have included photovoltaic panels as Waste of Electric and Electronic Equipment (WEEE) of type 4 . The Directive established target recycling rate $(65 \%$ by 2012 and $70 \%$ by 2015 ) and minimum recovery target for dedicated processes ( $75 \%$ in weight by 2012 and $80 \%$ by 2015). Accordingly each European Country adopted national regulations in order to fulfill EU directive objectives. Also consortia were promoted for take back and recycling just like PV Cycle, an association founded in 2007 by the photovoltaic industry to put in place and promote a take back and recycling program at European level.

\section{End Of Life Photovoltaic Panels As Secondary Raw Materials}

European Directive specified the importance of end of life photovoltaic panels as secondary raw materials specifying the minimum material recovery that recycling processes should guarantee. 
In Table 2 materials and rare metals which could be recovered by the different types of photovoltaic panels are reported along with their actual price and future exploitation previsions ${ }^{2}$.

\begin{tabular}{|l|c|l|l|l|}
\hline Materials & Price (euro/Kg) & Type of PV & $\begin{array}{l}\text { Estimated future } \\
\text { demand }\end{array}$ & $\begin{array}{l}\text { Current } \\
\text { recycling rate }\end{array}$ \\
\hline Glass & 0.05 & $\begin{array}{l}\text { Crystalline Si, } \\
\text { amorphous Si, } \\
\text { CdTe, CIS, } \\
\text { CIGS, CPV and } \\
\text { emerging } \\
\text { technologies }\end{array}$ & low & $64 \%$ \\
\hline Aluminum & 1.2 & $\begin{array}{l}\text { Crystalline Si, } \\
\text { amorphous Si, } \\
\text { CdTe, CIS, } \\
\text { CIGS, CPV and } \\
\text { emerging } \\
\text { technologies }\end{array}$ & & \\
Crystalline Si & high & $41-95 \%$ \\
\hline Ag & 650 & $\begin{array}{l}\text { Amorphous Si, } \\
\text { CIS, CIGS medium }\end{array}$ & $\begin{array}{l}\text { Limited but } \\
\text { increasing }\end{array}$ \\
\hline In & 442 & $\begin{array}{l}\text { CIGS, CPV and } \\
\text { emerging } \\
\text { technologies }\end{array}$ & medium & $20 \%$ \\
\hline Ga & 515 & $\begin{array}{l}\text { Amorphous Si, } \\
\text { CPV low } \\
\text { emerging and } \\
\text { technologies }\end{array}$ & & $30 \%$ \\
\hline Ge & 957 & &
\end{tabular}

Table 2. Recoverable materials from different types of photovoltaic panels.

Projections of end of life panel amounts that will be disposed of in the next years are reported in Figure 4 showing that huge amounts of these wastes are expected for 2035 and that thin film types will increase steadily over the years ${ }^{2}$.

\section{Recycling Technologies}

Scientific literature and patent survey denoted the use of different kinds of treatments for photovoltaic panel treatment: mechanical treatments (crushing, attrition, density separation, flotation), thermal treatments (incineration, pyrolysis, melting) and chemical treatments (acid/base treatment solvent treatment).

Even though a number of treatments were tested for photovoltaic recycling in laboratory scale ${ }^{3-8}$ there are currently only two processes that have been tested in large scale: the Deutsche Solar process and the First Solar process.

Deutsche Solar process was launched in Germany in 2003 and halted due to its costliness for the low quantities of photovoltaic panels at that time and the low automation level of the process.

Deutsche Solar process was designed for crystalline silicon panels to recover silicon wafer in intact solar cells by manual dismantling according to the process scheme reported in Figure 5. 


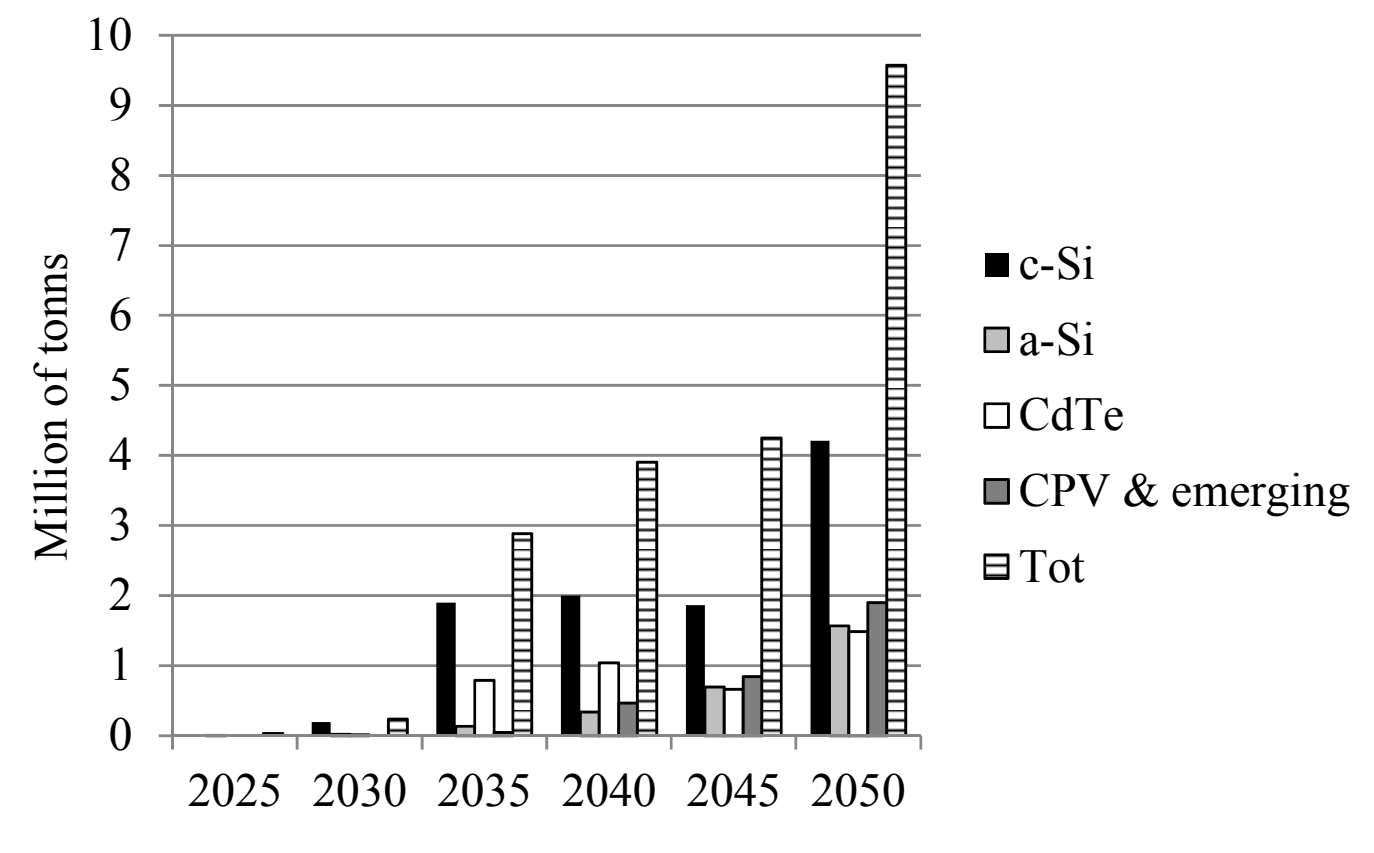

Figure 4. Projections of amounts of wastes (ton) disposed of during next years in EU countries.

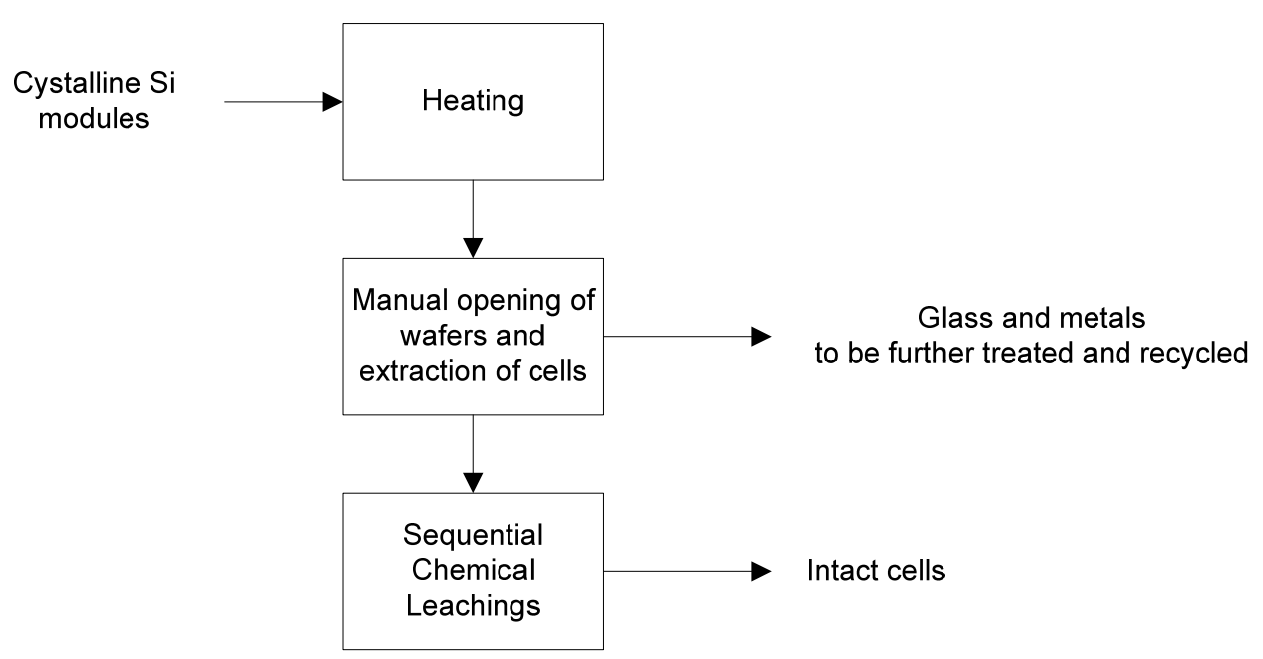

Figure 5. Block diagram for Deutsche Solar process for crystalline Si recycling.

Main process steps are:

- Heating and manual separation of wafers

- Manual separation of intact solar cells

- Chemical treatment of solar cells for the removal of metallization layer,

- Chemical treatment of solar cells for the removal of antireflective coating

- Chemical treatment of solar cells for the removal of $n$ doped layer

Glass and metals manually separated after initial thermal treatment were recycled according to conventional process routes. 
Main disadvantages of the process are the manual treatment of panels, the use of sequences of thermal and chemical operations involving mineral acids for solar cell treatment, the use limited to crystalline silicon panels.

First Solar process is currently operated in United States, Germany and Malaysia and is primarily used for CdTe panels treatment according to the process scheme reported in Figure 6.

The process consists of the following steps:

- Crushing and grinding

- Removing the semiconductor film by leaching with sulfuric acid and hydrogen peroxide.

- Physical separation EVA-glass through mechanical operations: classification and vibrating screen

- Precipitation of metals by addition of sodium hydroxide

In this process there is the recovery of $90 \%$ of the glass and about $95 \%$ of cadmium and tellurium which must still be subjected to a purification step.

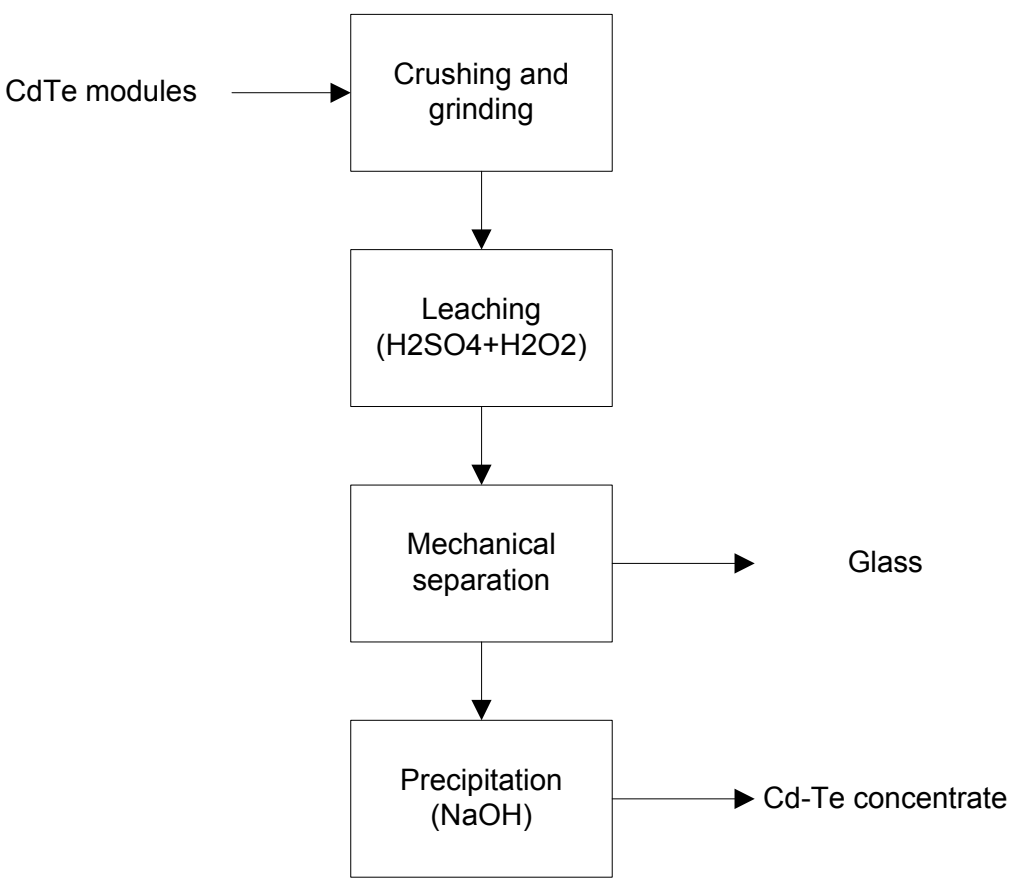

Figure 6. Block diagrams of First Solar process for CdTe panel recycling.

Main disadvantages of First Solar process is the treatment of the whole amount of waste by hydrometallurgical treatment and the use limited to CdTe panels.

In this work experimental results were reported for an innovative process for the treatment of different kinds of panels (crystalline $\mathrm{Si}$, amorphous $\mathrm{Si}, \mathrm{CdTe}$ ) according to the same process scheme including a pretreatment section and a hydrometallurgical section (Figure 7).

All physical pretreatments were performed in conventional equipment easily available for waste collectors not requiring specific design and high investment costs.

Then a simple and flexible process route, not requiring specifically designed equipment and high investments, can be used in order to make easily available and economically feasible the valorization of different kinds of photovoltaic panels in the same plant.

The specific sequence of physical operation was determined trying different combinations of crushing (single and multiple), milling (hammer mill and attrition mill) and thermal treatment ${ }^{9}$. Experimental results here reported referred to the optimal configuration tested for physical treatment. 


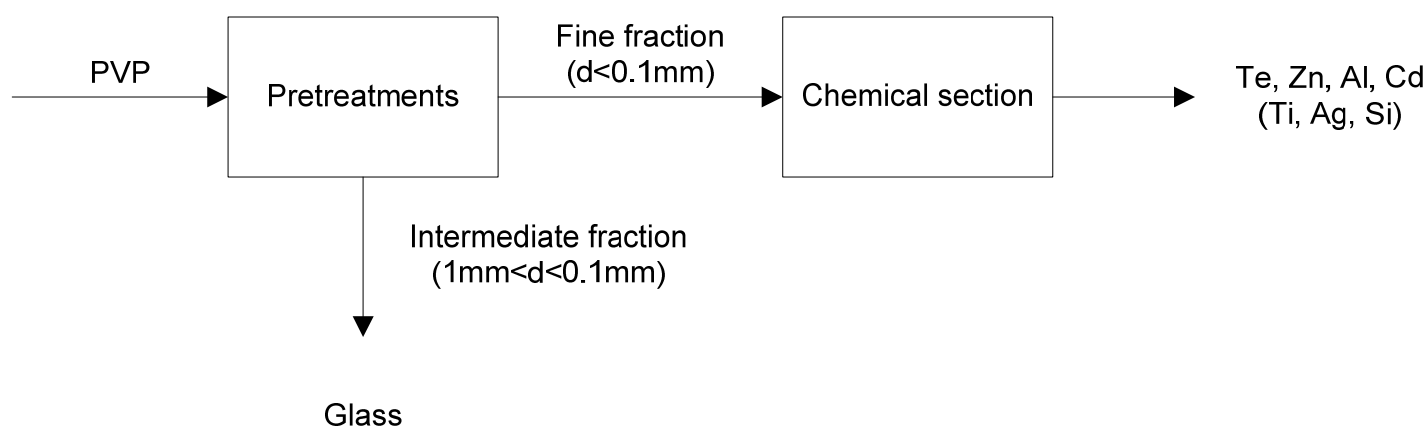

Figure 7. Schematic representation of the treatment of end of life panels according to the presented process scheme valid for different kinds of photovoltaic panels.

The process here discussed includes:

- manual dismantling of all electronic equipment (printed circuit boards) for the integral recovery of plastics and of precious metals therein (such as $\mathrm{Cu}, \mathrm{Au}, \mathrm{Ag}$ and $\mathrm{Pd}$ )

- manual dismantling of frames for the integral and direct recovery of aluminum,

- physical and chemical pretreatment of panels for glass recovery: automatic shredding of panels gives three fractions: a coarse fraction (containing EVA agglomerates), an intermediate fraction (directly recoverable as glass), a fine fraction (sent to hydrometallurgical section for metal recovery). The coarse fraction was thermally or chemically treated by solvents for EVA dissolution, then sieved giving further portions of intermediate fraction and fine fraction.

- hydrometallurgical section for metal recovery: fine fractions are treated by acid and/or alkaline leaching for extraction of $\mathrm{Te}, \mathrm{Zn}$ and $\mathrm{Al}, \mathrm{Fe}$ and $\mathrm{Cd}$, giving a residual solid as a concentrate of $\mathrm{Ti}, \mathrm{Ag}$ and $\mathrm{Si}$.

This approach has the advantage that only a small fraction of treated wastes (about $10-20 \%$ in weight) is treated for metal recovery by hydrometallurgical operations, requiring small units for such treatment and then low cost of investments.

Si recovery was not specifically addressed for different reasons:

- very low $\%$ of this constituent in photovoltaic panels (less than $1 \%$ still decreasing in new commercial products),

- recent dramatic diminution of electronic Si price (from $400 \$ / \mathrm{Kg}$ of 2008 to the current $200-40 \$ / \mathrm{Kg})$

- recent development in electronic Si production estimating $8 \$ / \mathrm{Kg}$ as final price.

Over all these reasons it should be also evident that the cost of electronic Si used in panel construction is not due to the cost of raw material but to the cost of production. Then except when a manual dismantling of Si cells is performed on intact panels (which is only a part of end of life panels), the recovery of reusable electronic Si cannot be technically and economically feasible.

\section{MATERIALS AND METHODS}

Experimental results reported in this work were obtained by using different kinds of photovoltaic panels: polycrystalline silicon module (BYD-230P6-30), monocrystalline silicon module (SHARP NT-175E1/NT-R5E3E), amorphous silicon PV module (Sharp NA-901 WQ), CdTe PV module (First Solar FS2). 
The silicon devices were previously manually disassembled in order to separate the modules from external frames and then, in each test, around $2 \mathrm{~kg}$ of photovoltaic modules were used as input materials.

Three successive crushing operations were carried out in a two blade rotors crusher (DR120/360, Slovakia) without any controlling sieve.

After size reduction, a sieving analysis was carried out to evaluate size and products distribution as well as mass fluxes in the process. For this purpose all samples were sieved by using 5 different sieves $(8 \mathrm{~mm}, 5 \mathrm{~mm}, 1 \mathrm{~mm}, 0.4 \mathrm{~mm}, 0.08 \mathrm{~mm})$ and an automatic shaker, then they were weighed.

Coarse fraction $(\mathrm{d}>1 \mathrm{~mm})$ was treated at $650{ }^{\circ} \mathrm{C}$ for 1 hour in a silite resistance furnace or with a mixture of acetone and cyclohexane aiming to a complete degradation of cross-linked EVA.

$0.2 \mathrm{~g}$ samples of recoverable glass fractions $(0.4-5 \mathrm{~mm})$ were tested by thermo gravimetric analysis to evaluate residual EVA traces after thermal treatment.

$0.2 \mathrm{~g}$ samples of recoverable glass fractions from CdTe panels were digested using sulfuric acid ( $9 \mathrm{ml}$ of a $96 \%$ solution) and hydrogen peroxide ( $1 \mathrm{ml}$ of a $35 \%$ vol solution) at $220{ }^{\circ} \mathrm{C}$ in a microwave digester (Milestone Ethos 900 Microwave Digestor). Liquid samples were filtrated and analyzed by Atomic Absorption Spectrophotometer, AAS (Analytik Jena ContrAA 300) for the determination of dissolved $\mathrm{Cd}$.

Fine fractions to be treated in hydrometallurgical section $(\mathrm{d}<0.4 \mathrm{~mm})$ were characterized by acid digestion with aqua regia $\left(\mathrm{HNO}_{3}+\mathrm{HCl}\right)$ and liquid samples analyzed by AAS.

Preliminary leaching tests in lab scale were performed. Acid leaching of fine fractions of monocrystalline, polycrystalline and amorphous $\mathrm{Si}$ were performed in $100 \mathrm{ml}$ leach solutions prepared using $\mathrm{H}_{2} \mathrm{SO}_{4} 5 \mathrm{M}$ and $5 \mathrm{ml}$ of $\mathrm{H}_{2} \mathrm{O}_{2}(30 \%)$ with a solid liquid ratio $1: 3$ for $3 \mathrm{~h}$ at $60^{\circ} \mathrm{C}$. After solid liquid separation by centrifugation the liquid was analyzed by $\mathrm{AAS}$ and the solid was further leached by using $\mathrm{H}_{2} \mathrm{SO}_{4} 10 \mathrm{M}$ and $\mathrm{H}_{2} \mathrm{O}_{2}(25 \mathrm{ml})$ at $100^{\circ} \mathrm{C}$ for $1 \mathrm{~h}$.

Basic leaching on the fine fraction from $\mathrm{CdTe}$ panels were performed using a solution with $\mathrm{NaOH} 5 \mathrm{M}$ and $\mathrm{H}_{2} \mathrm{O}_{2}$ at $100^{\circ} \mathrm{C}$ for $3 \mathrm{~h}$ varying the solid/liquid ratio $(0.5 \mathrm{~g} / 50 \mathrm{ml}$ and $1 \mathrm{~g} / 50 \mathrm{ml})$ and leaching temperature $\left(40\right.$ and $80{ }^{\circ} \mathrm{C}$ ) according to a factorial design. Liquid samples after solid/liquid separation were analyzed for extracted metals by AAS.

\section{RESULTS AND DISCUSSION}

\section{Physical Pretreatments}

Experimental results of physical pretreatment on the different types of photovoltaic module gave similar results in terms of weight distribution in the different size classes (Figure X).

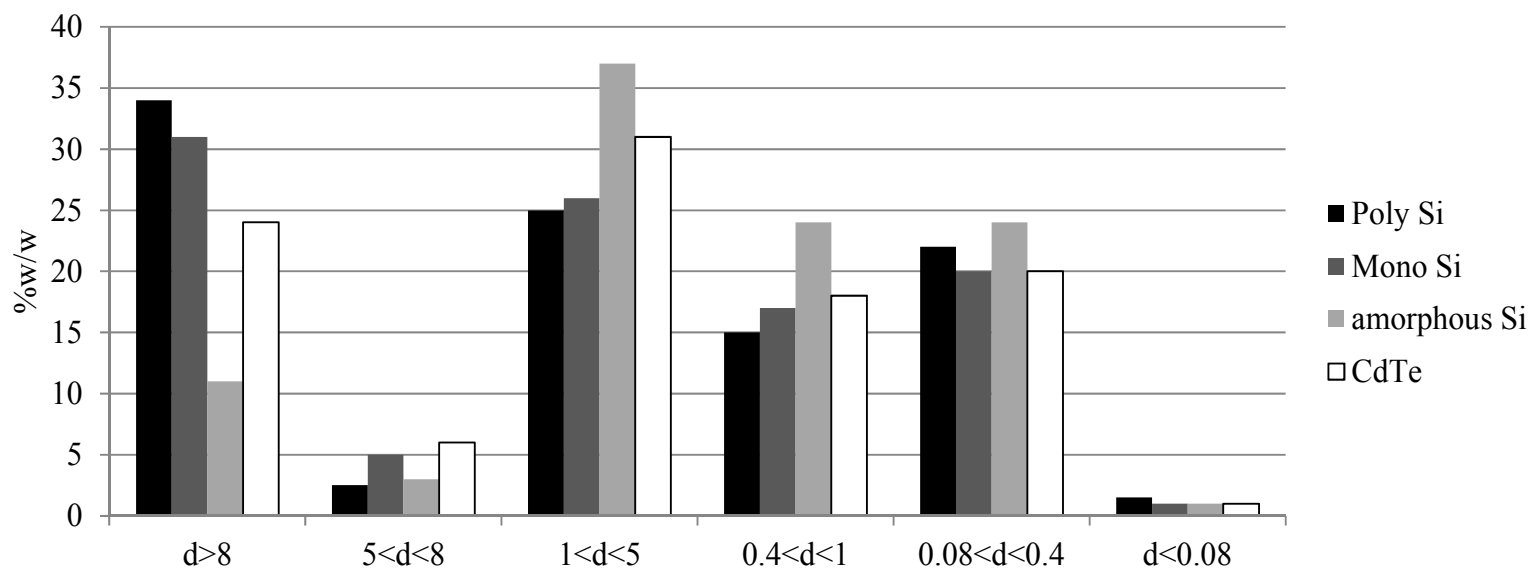

Figure 8. Particle size distribution in $\mathrm{mm}$ for the different panel types after triple crushing. 
Fractions larger than $1 \mathrm{~mm}$ required further treatment in order to break down EVA aggregates as evidenced in Figure 9. On the other side fractions $0.4-1 \mathrm{~mm}$ (about 20\% in weight) are directly recoverable as glass (Figure 10).

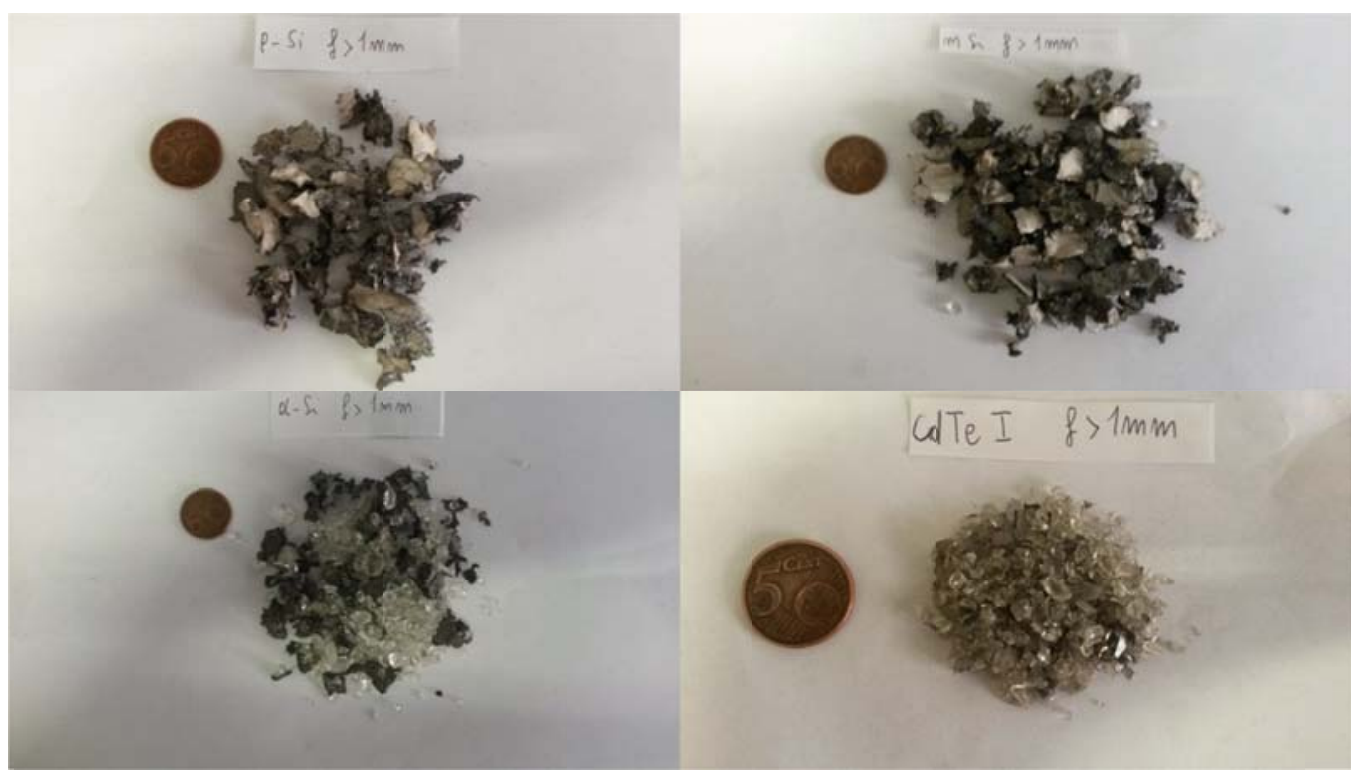

Figure 9. Fractions larger than $1 \mathrm{~mm}$ for the different panel types obtained after triple crushing.

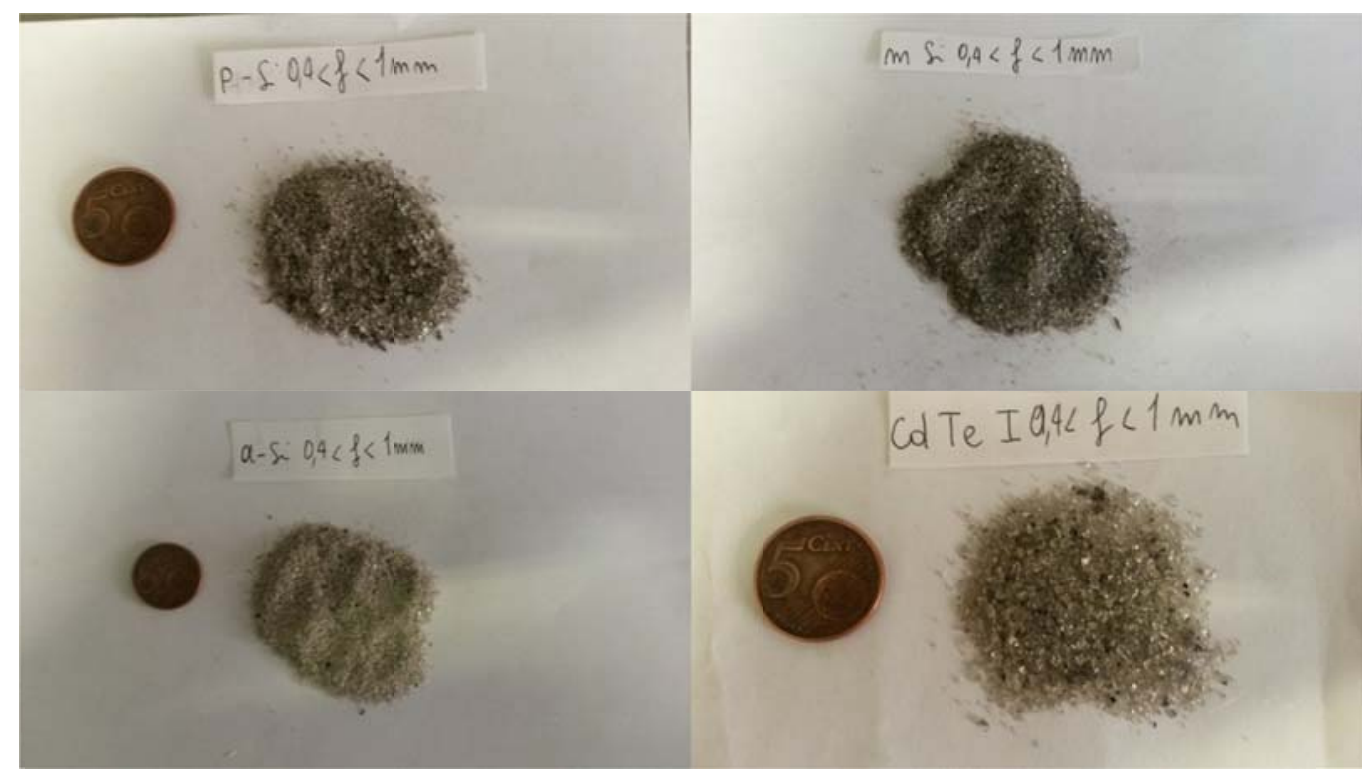

Figure 10. Fractions $0.4-1 \mathrm{~mm}$ for the different panel types obtained after triple crushing.

Fractions lower than $0.4 \mathrm{~mm}$ (Figure 11) contained significant amounts of metals and $\mathrm{Si}^{9}$ and can be processed in hydrometallurgical section.

Fractions larger than $1 \mathrm{~mm}$ were further treated by thermal treatment giving the size distribution reported in Figure 12.

Thermal treatment allowed to obtain about $80 \%$ of directly recoverable glass not depending on the type of panels. Post thermal treatment recoverable glass fractions $1-5 \mathrm{~mm}$ were reported in Figure 13. 
Less than $10 \%$ of fine fractions were obtained to be sent as the previously generated to the hydrometallurgical section and less than $10 \%$ of aggregates still remained with dimension larger than $5 \mathrm{~mm}$ that should be considered as a waste material.

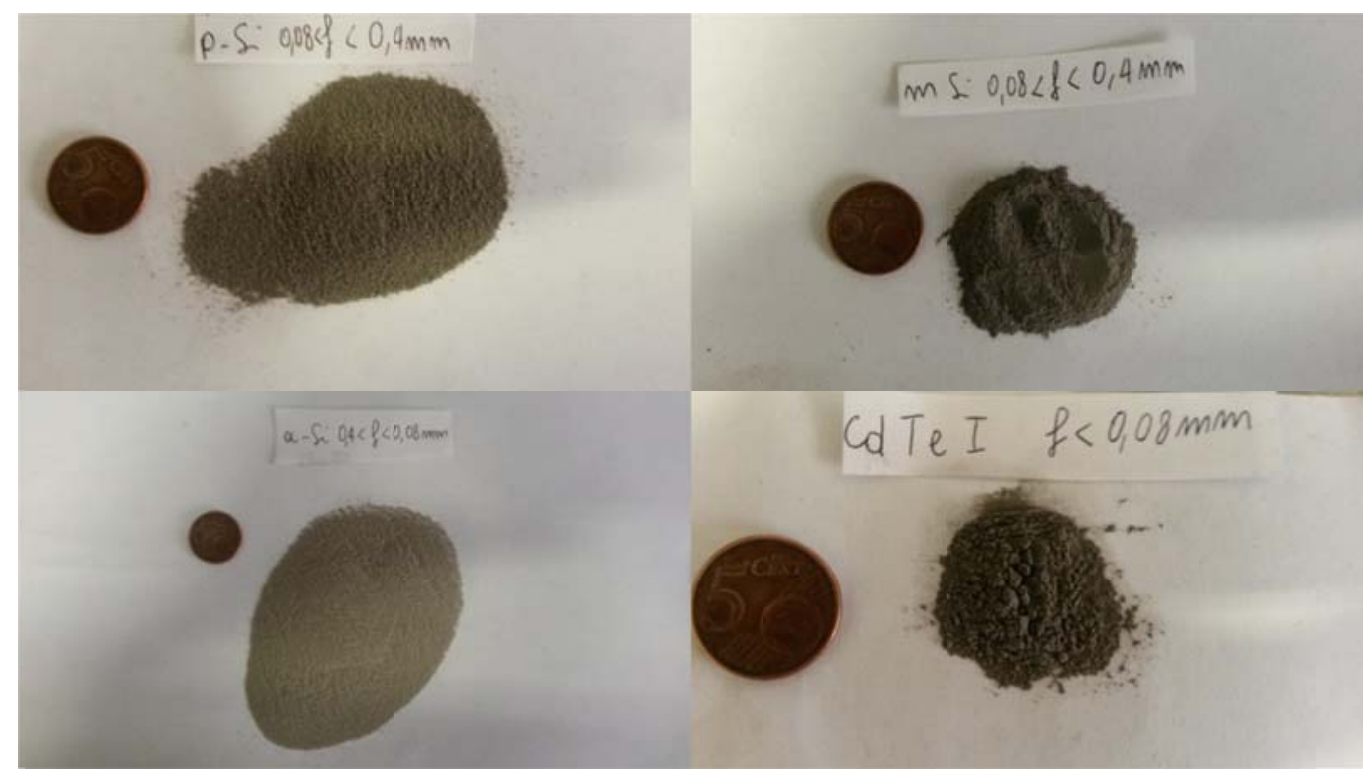

Figure 11. Fractions $0.4-0.08 \mathrm{~mm}$ for the different panel types obtained after thermal treatment.

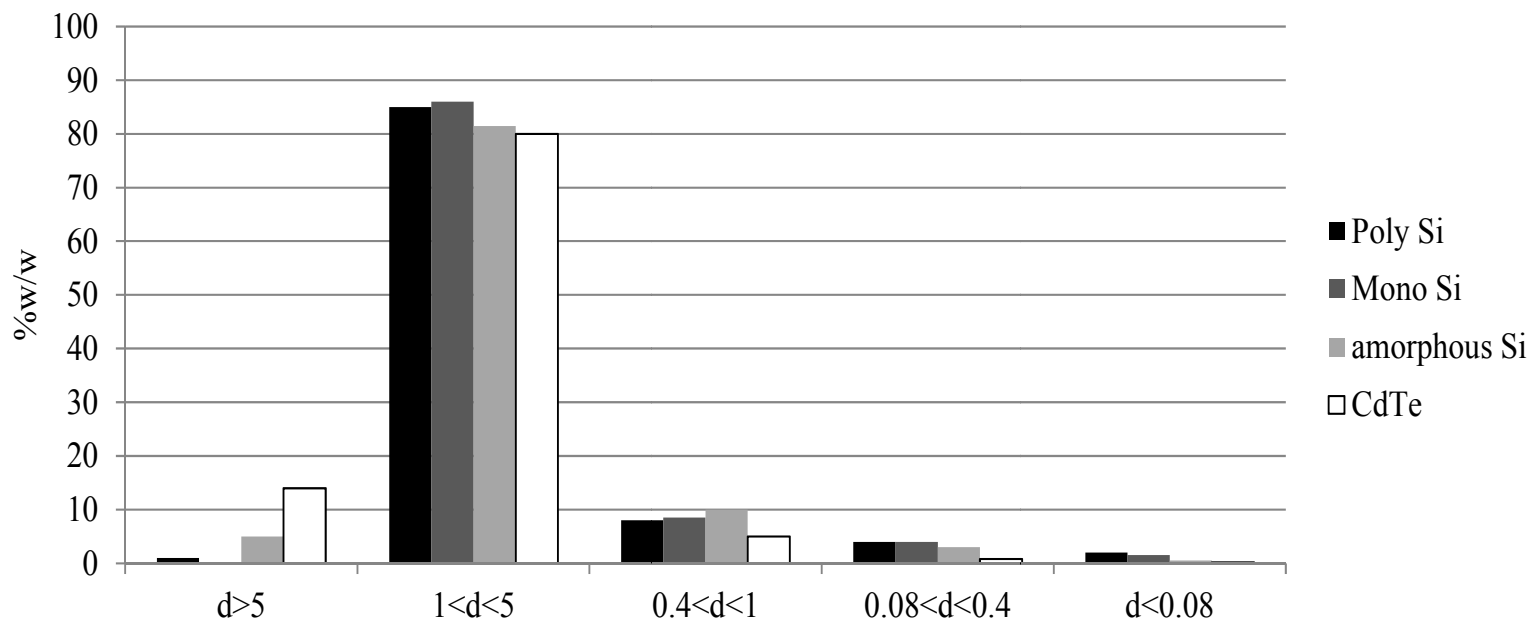

Figure 12. Particle size distribution in $\mathrm{mm}$ for the different panel types after thermal treatment. 


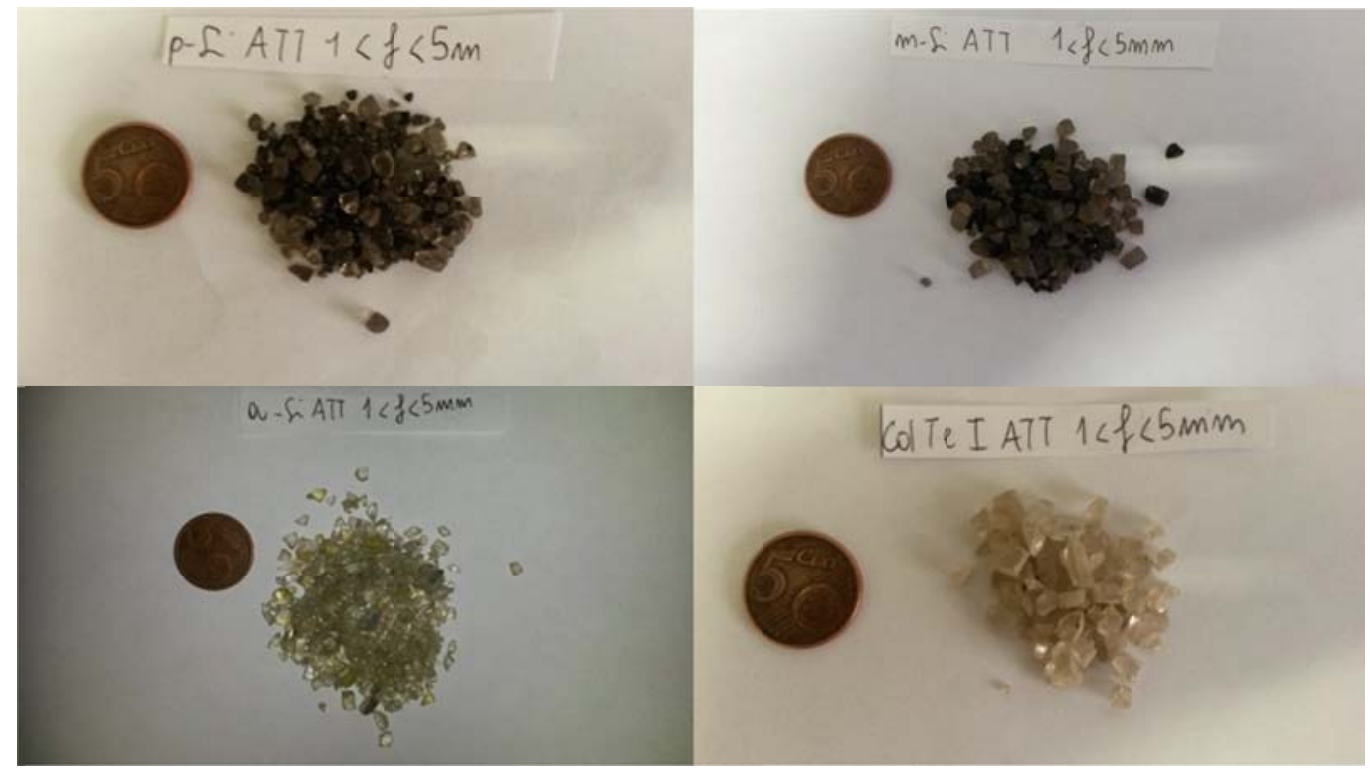

Figure 13. Fractions 1-5 mm for the different panel types obtained after thermal treatment.

The degree of glass-EVA separation was specifically addressed by performing thermo gravimetric analyses (TGA) of directly recoverable glass fractions obtained for the three types of panels (crystalline and amorphous silicon based panels and CdTe panel). TGA results showed (Figure 14) no thermal transition nearby the EVA decomposition temperature $\left(400-525{ }^{\circ} \mathrm{C}\right)^{10}$. Only very slight $(<0.3 \%)$ weight increase was observed probably due to oxidation of some residual powders coming from physical pretreatments.

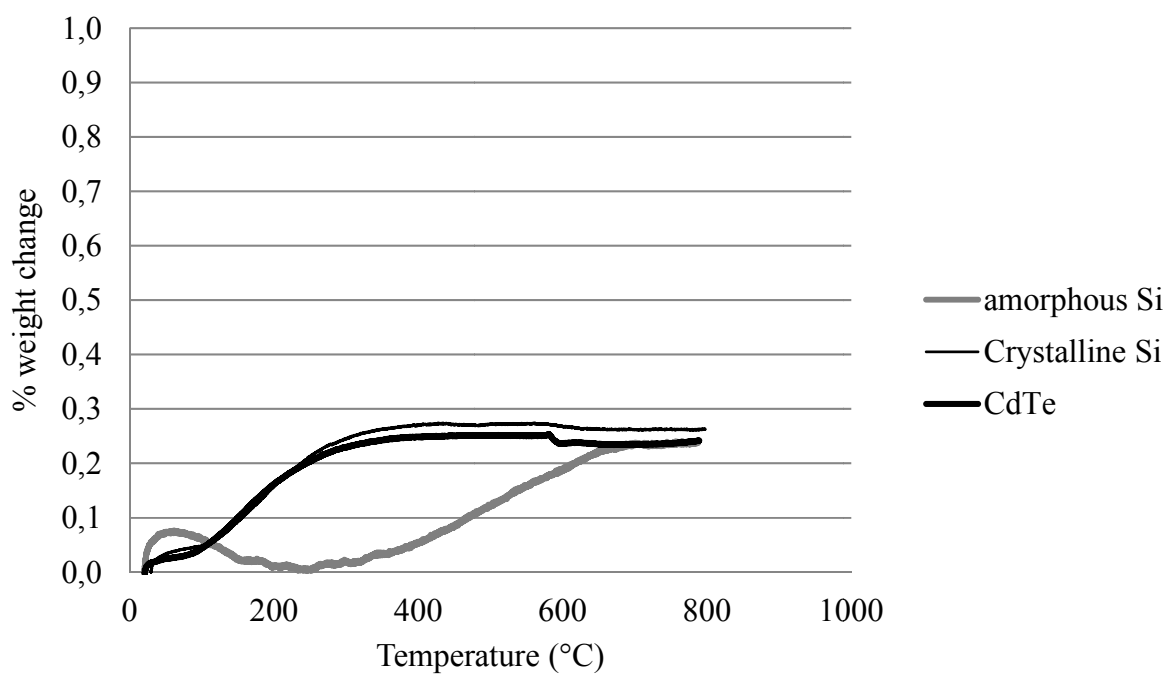

Figure 14. Weight change during thermal gravimetric experiments of the recoverable glass fractions of different panel types

Alternatively to thermal treatment EVA dissolution was performed by treatment with organic solvent mixture. Such treatment allowed complete removal of aggregates and clear clean glass recoverable fractions as reported in Figure 15. 


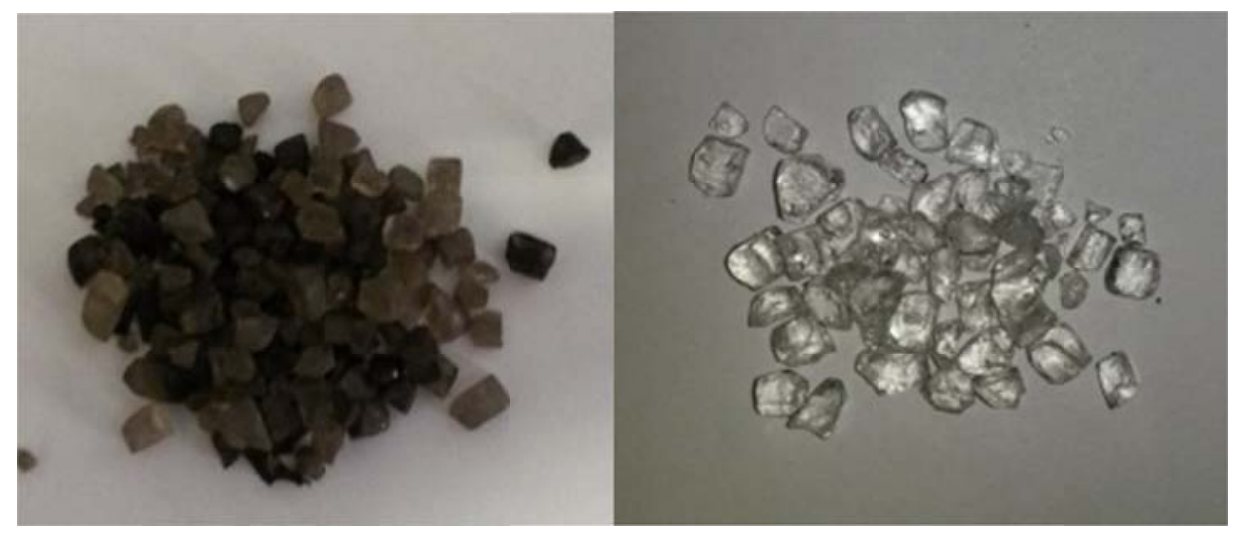

Figure 15. Comparison of recoverable glass fraction after thermal treatment (left) and solvent treatment (right).

In the case of CdTe panels reduction of $\mathrm{Cd}$ content in recoverable fraction is a process target. Mineralization tests on such samples showed Cd content of about $0.1 \mathrm{mg} / \mathrm{g}$ corresponding to $0.01 \%$ of $\mathrm{Cd}$. Then a partial reduction of $\mathrm{Cd}$ in recoverable fraction was attained. Further improvement could be achieved by physical treatment of glass in order to remove impurity particles (dark fragments in Figure 10) exploiting density differences (by flotation, pneumatic separation or vibrant table)

\section{Hydrometallurgical Treatment}

Acid digestion by mineralization of fine fractions $(<0.4 \mathrm{~mm})$ without thermal treatment as resulting from triple crushing and after thermal treatment were reported in Table 3.

\begin{tabular}{|c|c|c|c|c|c|c|c|c|c|c|c|}
\hline & $\%_{\mathrm{w} / \mathrm{w}}$ & $\mathrm{Ti}$ & $\mathrm{Zn}$ & $\mathrm{Al}$ & $\mathrm{Fe}$ & $\mathrm{Sn}$ & $\mathrm{Ag}$ & $\mathrm{Cu}$ & $\mathrm{Cd}$ & $\mathrm{Te}$ & $\mathrm{SiO} 2$ \\
\hline \multirow{2}{*}{$\begin{array}{c}\text { Without } \\
\text { thermal } \\
\text { treat }\end{array}$} & $\mathrm{mSi}$ & 0.11 & 1.21 & 0.78 & 1.67 & - & 0.05 & 0.03 & - & - & 40.8 \\
\cline { 2 - 14 } & $\mathrm{pSi}$ & 0.04 & 0.89 & 0.51 & 1.96 & - & 0.09 & - & - & - & 46.5 \\
\cline { 2 - 13 } & $\mathrm{aSi}$ & 0.33 & 0.69 & 0.39 & 1.03 & - & 0.01 & - & - & - & 46.8 \\
\cline { 2 - 13 } & $\mathrm{CdTe}$ & - & 1.50 & 0.40 & 1.79 & 0.93 & - & - & 0.16 & 0.19 & 47.7 \\
\hline \multirow{2}{*}{$\begin{array}{c}\text { After } \\
\text { thermal } \\
\text { treat }\end{array}$} & $\mathrm{mSi}$ & 0.09 & 0.99 & 0.91 & 1.78 & - & 0.09 & 0.02 & - & - & 42.3 \\
\cline { 2 - 12 } & $\mathrm{pSi}$ & 0.06 & 0.61 & 0.43 & 1.9 & - & 0.08 & 0.05 & - & - & 43.5 \\
\cline { 2 - 12 } & $\mathrm{aSi}$ & 0.35 & 0.75 & 0.35 & 0.7 & - & 0.03 & 0.05 & - & - & 49.8 \\
\cline { 2 - 11 } & $\mathrm{CdTe}$ & - & 1.36 & 0.99 & 0.93 & 0.87 & - & - & 0.3 & 0.21 & 49.3 \\
\hline
\end{tabular}

Table 3. Chemical composition of fine fractions determined by acid digestion.

These data evidenced the presence of valuable metals in fine fractions with content not affected by thermal treatment. These metals can be extracted and valorized in a hydrometallurgical section.

Distinct hydrometallurgical routes can be followed depending of the feed composition: if Sibased panels were preliminarily separated by CdTe panels the fine fractions will be treated separately. Then fine fraction emerging from Si-based panels can be treated by mild acid leaching for the separation of $\mathrm{Zn}, \mathrm{Al}$, and $\mathrm{Fe}$ and the obtainment of a concentrate containing $\mathrm{Ag}$ and $\mathrm{Ti}$ which could be also further refined to give $\mathrm{Ag}$ and $\mathrm{Ti}$ as separated products. On the other 
hand the fine fraction resulting from CdTe treatment can be leached by alkali for sequential extraction of Te, $\mathrm{Al}$ and $\mathrm{Zn}$ leaving a concentrated containing $\mathrm{Cd}$ which can be further treated by acid leaching to extract $\mathrm{Cd}$. Otherwise if no preliminary separation is performed between Sipanels (crystalline and amorphous) and CdTe panels, the fine fraction can be treated in the hydrometallurgical section according to a sequential scheme of basic and acid leaching allowing the separation of the different metals.

Preliminary experimental results of sequential leaching performed using fine fractions emerging from pilot plant tests were reported here.

Fine fractions emerging from monocrystalline, polycrystalline and amorphous Si panels were preliminary leached in mild conditions to extract $\mathrm{Zn}, \mathrm{Al}$ and Fe (Figure 16). Residual solid mainly containing $\mathrm{Ti}, \mathrm{Si}$ and $\mathrm{Ag}$ was further treated in stronger leaching conditions in order to extract $\mathrm{Ti}$ (Figure 16). By this way a final residual solid containing Ag and Si was obtained.

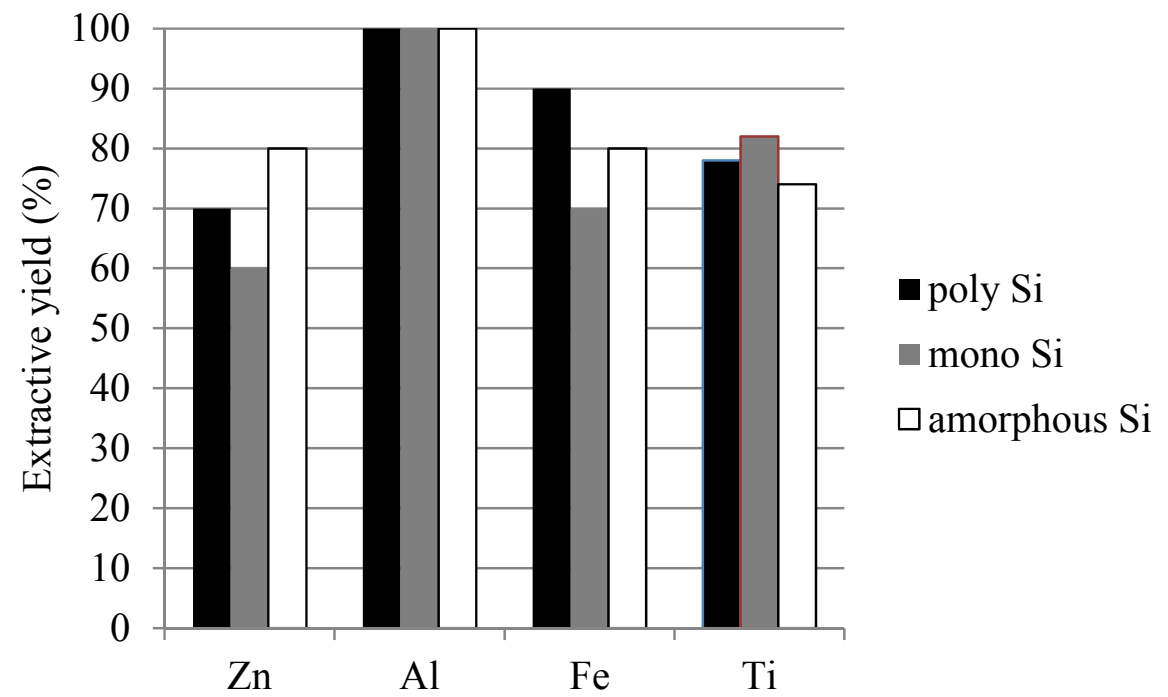

Figure 16. Sequential leaching of $\mathrm{Zn}, \mathrm{Al}, \mathrm{Fe}$ and Ti using the fine fractions of Si panels.

Experimental results of basic leaching in different operating conditions denoted that $\mathrm{Cd}$ extraction is always zero, while a selective extraction of Te can be obtained working at $80{ }^{\circ} \mathrm{C}$ (Figure 17).

After this step extraction the residual containing $\mathrm{Cd}$ can be further treated by acid or directly inertised being $5-10 \%$ of initial waste. 


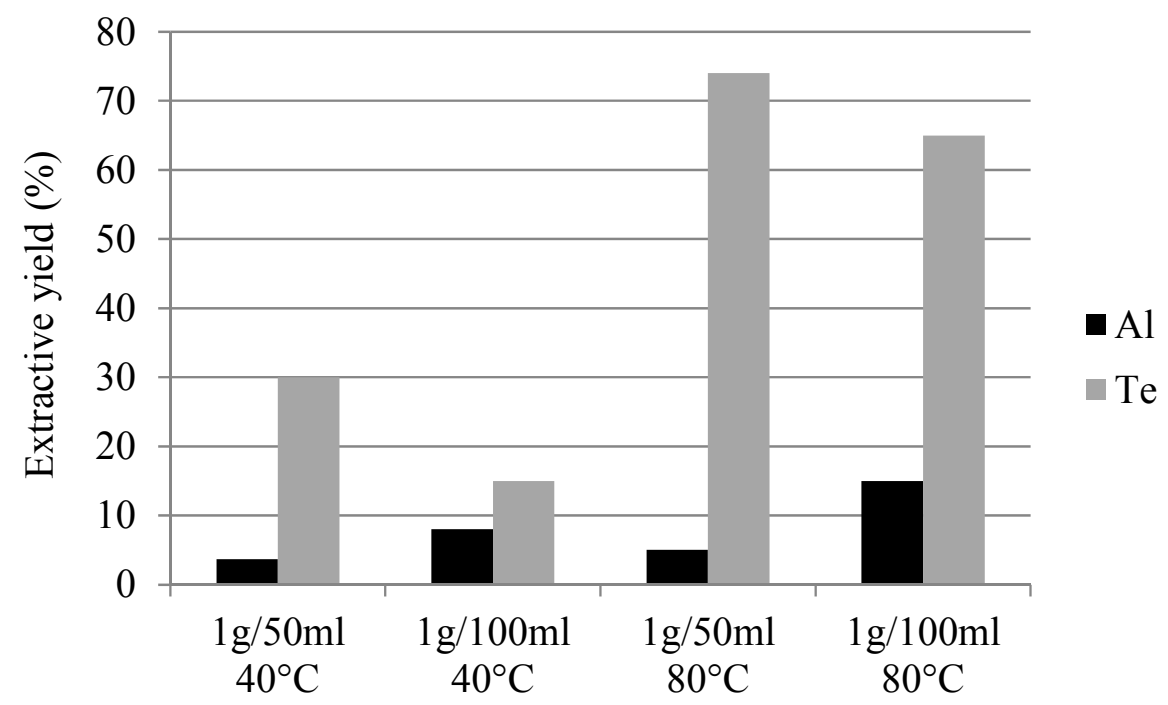

Figure 17. Extractive yields of $\mathrm{Al}$ and $\mathrm{Te}$ in different basic leaching conditions using fine fraction form CdTe panels.

\section{CONCLUSIONS}

In this work a review of the status of the recycling activities for photovoltaic panels was reported along with pilot scale experimental results for the treatment of various types of panels according to the same process route.

This process allowed $70 \%$ recovery of the module weight (without frame and other equipment) as glass and the treatment by hydrometallurgical operations of only the $20 \%$ of the module weight.

A pilot scale installation with a potentiality of 200 ton/year is going to be realized including physical pretreatment and solvent treatment for the recovery of aluminum and glass from end of life panels, in which the previously described route will be assessed. This pilot plant will comprehend the operations described in Figure 18.

Fine fractions and electronic equipment included in photovoltaic installations will be treated according to hydrometallurgical operations in a mobile pilot plant already built within FP7 founding scheme (HydroWEEE project).

After fulfilling of targets related to photovoltaic panels the same integrated units (physical pretreatment and hydrometallurgical section) will be used to implement the pretreatment section in other processes already developed for the hydrometallurgical section for similar wastes such as liquid crystal display (HydroWEEE DEMO project). 


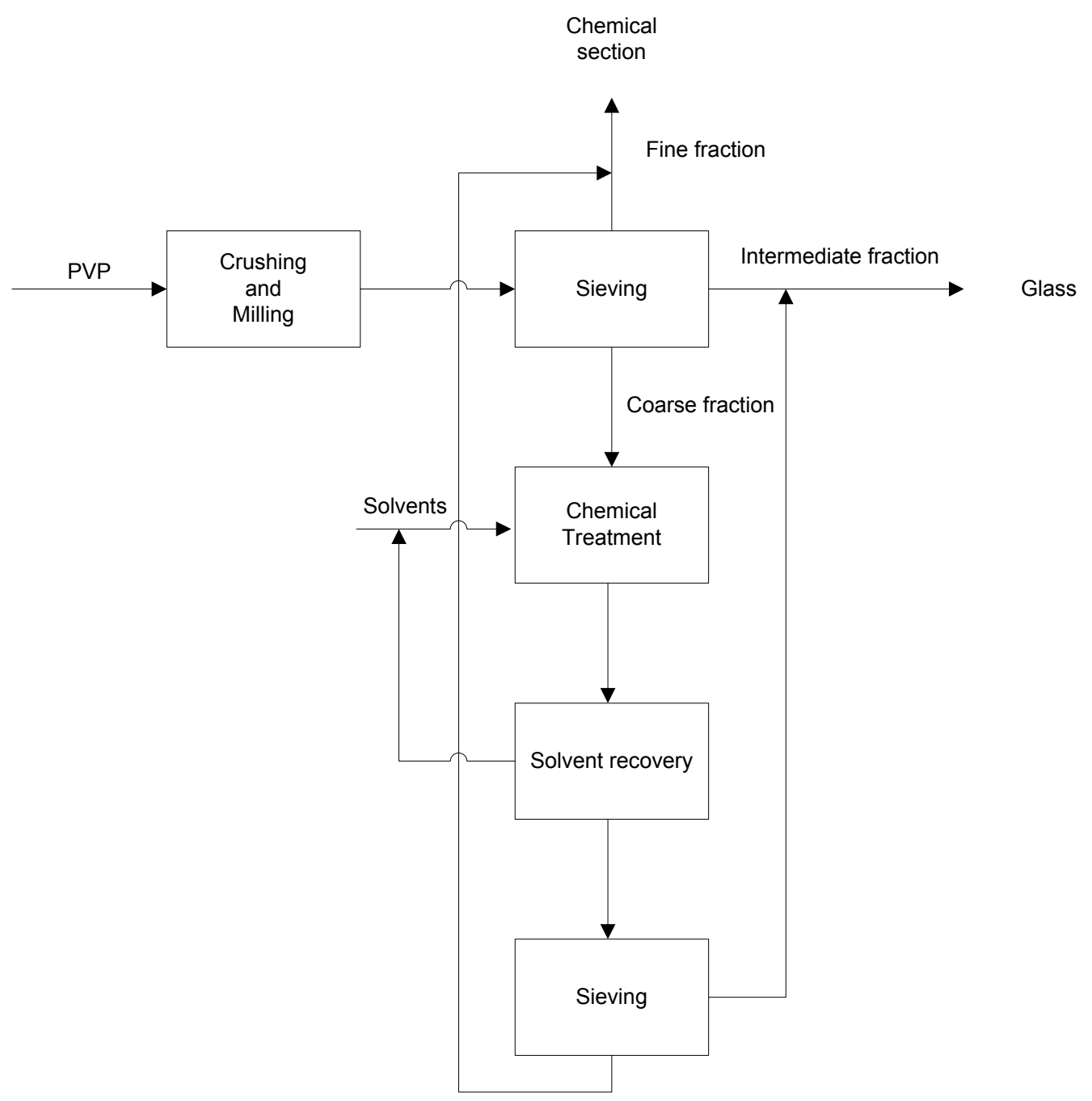

Figure 18. Block diagram for the pretreatment operations included in the pilot plant unit.

\section{Acknowledgment}

I'd like to thank all the members of the research team of High Tech Recycling Center working in the Department of Chemistry of Sapienza University, and in particular prof. Luigi Toro, Dr. Giuseppe Granata, Dr. Emanuela Moscardini and Mr. Thomas Abo Atia for their continuous collaboration and fundamental contribution.

I'd like to thank also Professor Havlik which makes possible the realization of pilot scale tests for physical pretreatment with the equipments of the Department of Non-ferrous Metals and Waste Treatment in the Technical University of Kosice in Slovakia.

\section{REFERENCES}

${ }^{1}$ http://www.solarfeeds.com/update-global-solar-market/

${ }^{2}$ Solar PV end of life environmental impact study, Green Tech (http://energy.wesrch.com/pdfTR1L024TVPSCZ)

${ }^{3}$ D.Takuya, T. Izumi, U. Hiroaki, M. Akinobu, S. Koichi, K. Kosuke: Experimental study on PV module recycling with organic solvent method, Solar Energy Materials \& Solar Cells, 67(2001), $397-403$ 
${ }^{4}$ E. Klugmann-Radziemska, P. Ostrowski, K. Drabczyk, P. Panek, M. Szkodo: Experimental validation of crystalline silicon solar cells recycling by thermal and chemical methods, Solar Energy Materials \& Solar Cells 94(2010), 2275-2282

${ }^{5}$ E. Klugmann-Radziemska, P. Ostrowski: Chemical treatment of crystalline silicon solar cells as a method of recovering pure silicon from photovoltaic modules, Renewable Energy 35(2010), 1751-1759.

${ }^{6}$ W. Berger, F.G. Simon, K. Weimann, E. A. Alsema: A novel approach for the recycling of thin film photovoltaic modules, Resources, Conservation and Recycling 54(2010), 711-718.

${ }^{7}$ S. Menezes: Electrochemical approach for removal, separation and retrieval of CdTe and CdS films from PV module waste, Thin Solid Films, 387(2001), 175-178.

${ }^{8}$ E. Radziemska: Chemical treatment of crystalline silicon solar cells as a main stage of PV modules recycling, Ecological Chemistry and Engineering, 16(2009), 379-387.

${ }^{9}$ G. Granata, F. Pagnanelli, E. Moscardini, T. Havlik, L. Toro: Recycling of photovoltaic panels by physical operations. Solar Energy Materials \& Solar Cells 123(2014), 239-248.

${ }^{10}$ M. L. Marín, A. Jiménez, J. López, J. Vilaplana: Thermal degradation of ethylene (vinyl acetate), J. Therm. Anal. 47(1996), 247-258. 